\title{
Blown by the Wind
}

\section{Replacing Nuclear Power in German Electricity Generation}

Originally published as:

Stefan Lechtenböhmer, Sascha Samadi (2013):

Blown by the wind. Replacing nuclear power in German electricity generation In: Environmental Science \& Policy, Volume 25, January 2013, 234-241

DOI: 10.1016/j.envsci.2012.09.003 
Stefan Lechtenböhmer ${ }^{*}$, Sascha Samadi

\section{Blown by the Wind}

\section{Replacing Nuclear Power in German Electricity Generation}

Wuppertal Institute for Climate, Environment and Energy, Germany

* Corresponding author: Stefan Lechtenböhmer, Wuppertal Institute for Climate, Environment and Energy, Döppersberg 19, 42103 Wuppertal, Germany

E-mail: stefan.lechtenboehmer@wupperinst.org

Phone: १० 9-202-2492-216

Fax: $+49-202-2492-198$ 


\begin{abstract}
Only three days after the beginning of the nuclear catastrophe in Fukushima, Japan, on 11 March 2011, the German government ordered 8 of the country's 17 existing nuclear power plants (NPPs) to stop operating within a few days. In summer 2011 the government put forward a law - passed in parliament by a large majority - that calls for a complete nuclear phase-out by the end of 2022. These government actions were in contrast to its initial plans, laid out in fall 2010, to expand the lifetimes of the country's NPPs.
\end{abstract}

The immediate closure of 8 NPPs and the plans for a complete nuclear phase-out within little more than a decade, raised concerns about Germany's ability to secure a stable supply of electricity. Some observers feared power supply shortages, increasing $\mathrm{CO}_{2}$ emissions and a need for Germany to become a net importer of electricity.

Now - a little more than a year after the phase-out law entered into force - this paper examines these concerns using a) recent statistical data on electricity production and demand in the first 15 months after the German government's immediate reaction to the Fukushima accident and $b$ ) reviews the most recent projections and scenarios by different stakeholders on how the German electricity system may develop until 2025, when NPPs will no longer be in operation.

The paper finds that Germany has a realistic chance of fully replacing nuclear power with additional renewable electricity generation on an annual basis by 2025 or earlier, provided that several related challenges, e.g. expansion of the grids and provision of balancing power, can be solved successfully. Already in 2012 additional electricity generation from renewable energy sources in combination with a reduced domestic demand for electricity will likely fully compensate for the reduced power generation from the NPPs shut down in March 2011.

If current political targets will be realised, Germany neither has to become a net electricity importer, nor will be unable to gradually reduce fossil fuel generated electricity. Whether the reduction in fossil fuel use will be sufficient to adequately contribute to national greenhouse gas mitigation targets significantly depends on an active policy to promote electricity savings, continuous efforts to increase the use of renewables and a higher share of natural gas (preferably used in combined heat and power plants) in fossil fuel power generation.

\title{
1 Introduction
}

Less than a week after the beginning of the nuclear catastrophe in Fukushima, Japan, on 11 March 2011, the German government ordered 8 of Germany's 17 existing nuclear power plants (NPPs) to stop operating for an initial 3-month evaluation period. These were the 7 oldest NPPs still in operation in Germany at that time plus the NPP 'Krümmel' in northern Germany, which had previously suffered from various technical problems. Two of these 8 NPPs had not been in operation since 2007 and 2009 respectively due to technical reasons. In the summer of 2011 a law came into force that finally terminated the operating licenses of those 8 plants, with an instruction for the remaining 9 NPPs to be closed down successively by the end of 2022. In making this decision, the government basically returned to the nuclear phase-out plan that had originally been implemented by a previous government in 2002 but had been modified by the current - then newly elected - government in October 2010, granting an average of 12 additional operating years to all 17 NPPs ${ }^{1}$.

\footnotetext{
${ }^{1}$ For more details on Germany's nuclear policy before and after Fukushima, see e.g. Wittneben (2011), Jahn/Korolczuk (2012) or Bosman (2012).
} 
The decision to shut down 8 NPPs immediately and to phase-out the remaining NPPs in the years to come raised concerns about Germany's ability to secure a stable supply of electricity. Critics warned of rising electricity prices and a considerable increase in Germany's fossil fuel based power generation, with related increases in $\mathrm{CO}_{2}$ emissions. Some people also predicted that Germany would become a significant net importer of electricity from neighbouring countries, including nuclear electricity from France and the Czech Republic.

This paper does not aim to analyse what would have happened to $\mathrm{CO}_{2}$ emissions and electricity prices if the decisions to extend the lifetimes of the existing NPPs had not been reversed after the Fukushima accidents. Rather, it attempts to provide a) a preliminary assessment of the immediate changes brought about in the electricity market following the shut down of 8 NPPs in March 2011 and b) a projection showing how the decrease in nuclear generation will be compensated for until 2025 and what effects this may have on electricity prices and $\mathrm{CO}_{2}$ emissions.

\section{Methodology}

To analyse the short-term effects of the instant loss of around $40 \%$ of the country's nuclear power capacity, we take the electricity production of the year 2010 as a reference to reflect the typical electricity market situation in an annual period unaffected by the phase-out decision ${ }^{2}$. In 2010, 15 of the 17 nuclear power plants (NPPs) produced 141 TWh of gross electricity ${ }^{3}$. Official energy projections in 2010, which analysed the effects of the prolongation of nuclear lifetimes (BMWi 2010; Nagl et al. 2011) ${ }^{4}$, predicted similar levels of production until 2020. Renewables contributed 103 TWh in 2010. Net electricity exports were at $18 \mathrm{TWh}$, a level that had been relatively constant since 2006 (14 to $22 \mathrm{TWh} / \mathrm{a}$ ).

Our comparison comprises three stages. Firstly, in section 3 we examine the changes in the German electricity system with regards to both the short-term effects from 2011 to 2013, as well as the longer-term outlook to 2025 (a few years after the completion of the nuclear phase-out). For the second stage, we use the most recently available key energy scenarios and political targets in section 4 to provide one 'optimistic' and one 'pessimistic' scenario on the replacement of nuclear electricity and its effects on $\mathrm{CO}_{2}$ emissions until 2025. Finally, in order to evaluate the effects of the nuclear phase-out on electricity prices, we discuss in section 5 the results of several modelling studies conducted in recent years. Section 6 concludes.

\footnotetext{
${ }^{2}$ As levels of electricity generation, as well as net exports, traditionally fluctuate significantly on a seasonal basis it is important to either look at entire years instead of single months when comparing periods before and after the shutdown of NPPs or to compare a certain period of a year only with the same period of another year.

${ }^{3}$ Annual electricity generation from nuclear power in 2010 was at a similar level as in the years between 2007 and 2009 (135 to 149 TWh/a).

4 Those scenarios of the study with lifetime extensions for NPPs predicted production levels of about 149 TWh for 2020 followed by a decline in later years.
} 


\section{Changes in power generation due to nuclear phase-out}

\subsection{Short-term effects until 2013}

Based on preliminary statistical data on power generation in 2011 (BDEW, 2011, 2012a, AG Energiebilanzen 2012) and on the typical production over the previous decade of the nuclear power plants still in operation (IAEA, 2012), we estimate that the permanent shutdown of the eight NPPs in March 2011 resulted in a potential 'loss' of nuclear electricity generation of 32.5 TWh in 2011 and will result in a loss of around 41 TWh/a in both 2012 and $2013^{5}$. Relating the loss of nuclear power generation of the years 2012 and 2013 to actual electricity generation in 2010, this loss is equivalent to almost $30 \%$ of nuclear power generation and to about 7\% of all electricity generation in Germany. After the permanent shutdown of the eight NPPs, the loss of nuclear power production was mostly compensated for by a combination of increased renewable electricity generation, reduced net electricity exports and reduced domestic electricity demand, as the figure shows.

Electricity generation, net electricity exports and domestic electricity demand in Germany show typical seasonal patterns. Therefore the picture of what has changed in German electricity supply and demand since Fukushima becomes clearer when the same periods of different years are compared. This serves the purpose of eliminating seasonal effects, which can otherwise mask the de facto changes. Based on (preliminary) energy statistics, Figure 1 shows the quarterly changes in electricity supply and demand in 2011 and the first half of 2012 as compared to the respective quarters in the reference year 2010.

The figure shows that in the first quarter of 2011, which was largely unaffected by the shutdown of NPPs, German electricity supply and demand was similar to the first quarter of 2010. Electricity generation from renewables was up by about 3 TWh and nuclear power production and electricity demand were both slightly higher (note that a negative demand reduction in the figure corresponds to an increase in demand) while exports were slightly lower. Fossil fuels can be seen as providing the required remaining electricity generation, which was about 5 TWh lower than in the first quarter of 2010.

\footnotetext{
${ }^{5}$ In this paper we use 2010 as the reference year for the analysis. In 2010, 15 NPPs had a gross production of 141 TWh (BDEW, 2011). 2 NPPs were out of operation throughout the entire year for technical reasons. Both of these are among the 8 NPPs that were permanently shut down in 2011.
} 


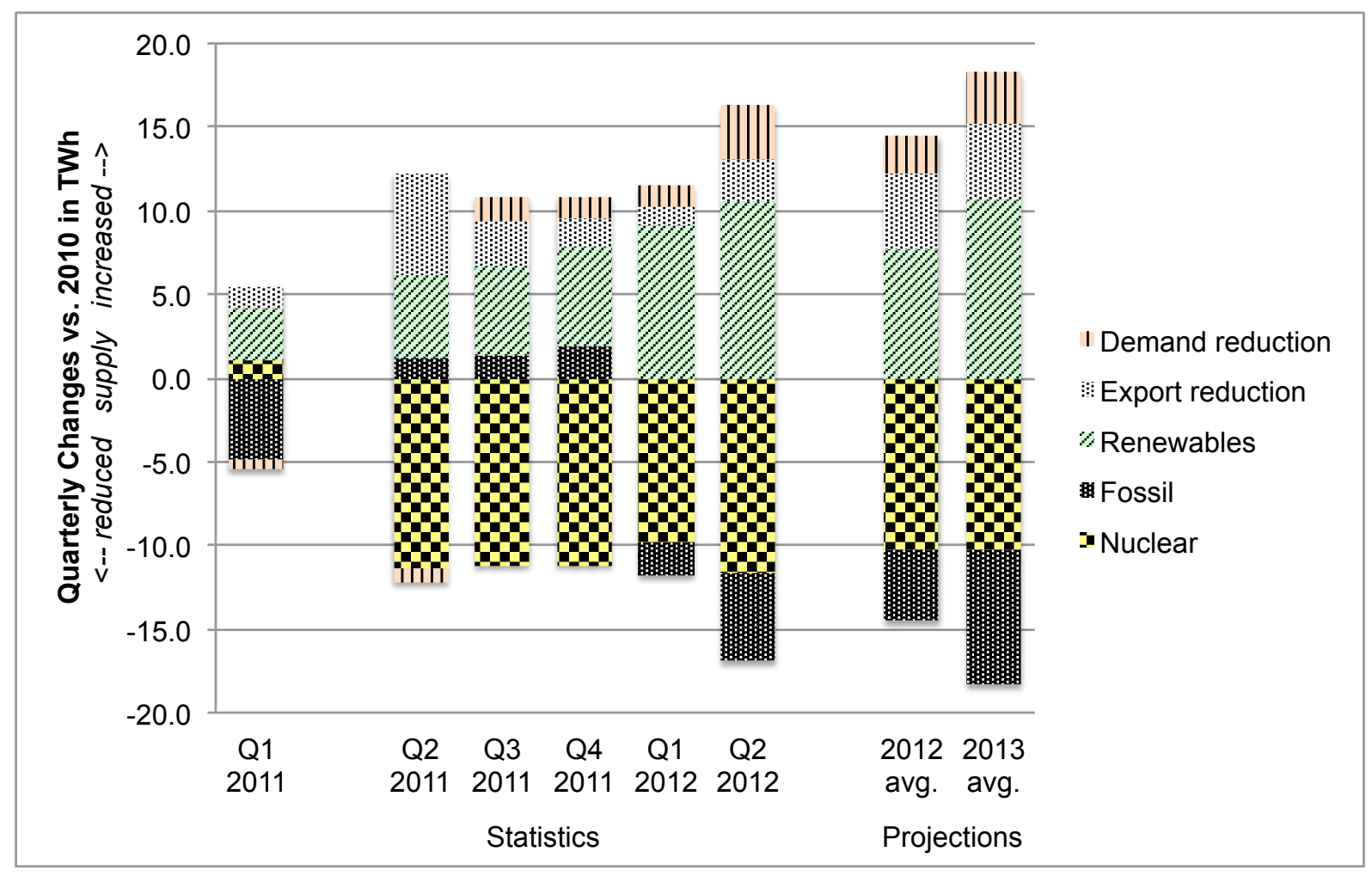

Figure: Changes in the German quarterly electricity supply and demand balance compared to the respective periods in 2010 for all four 2011 quarters, the first two quarters of 2012 and for projections for the years 2012 and 2013 (average per quarter) (own calculations based on AG Energiebilanzen 2012, BDEW 2011, 2012a, 2012b, 2012c; destatis 2012; for further data see Table S1 of supplementary material)

With the permanent shutdown of eight NPPs (six of which were operating throughout 2010) the picture changed significantly from the second quarter of 2011 on. Nuclear power generation was about 10 to 12 TWh lower in all of the last three quarters of 2011 and the first two quarters of 2012 - a reduction that can be expected to be roughly constant until the end of 2013. In the second quarter of 2011 this reduced nuclear power supply was compensated mainly by an increased generation from renewables (5 TWh) and a significant reduction in net exports (6 TWh).

The next four quarters from July 2011 to June 2012 showed a gradual adaptation of the demand and supply balance to the new situation. Electricity generation from renewables increased successively and reached a plus of almost 11 TWh in Q2 2012. At the same time electricity demand did not further increase but fell slightly below 2010 levels and net exports increased again - although they did not fully recovered from their 2010 levels until Q2 2012. Increasing electricity generation from renewables, lower net exports and (slightly) lower domestic power demand combined to limit the need for an increase in fossil power generation to a very moderate level ( 1 to 2 TWh per quarter) in the last three quarters of 2011. The same effects, especially a further increase in electricity generation from renewables even allowed fossil fuel power generation to be reduced in 2012 by 2 TWh (Q1) and 5 TWh (Q2) compared to the respective quarters of 2010 . As the projections for 2012 and 2013 show, this pattern is expected to last over the coming years.

It is worth pointing out two further insights that Figure 1 offers in regard to the amount of electricity generated by renewable sources in Q2 2012: First, in that quarter renewa- 
ble electricity generation reached a level that projections from fall 2011 expected to be reached only by $2013 .{ }^{6}$ And second, the additional electricity generation from renewables in that quarter compared to 2010 has already almost entirely compensated the loss of electricity generation from the six (previously operational) NPPs shut down in spring 2011.

For a preliminary analysis of the entire year 2012 and the year 2013, recent projections of electricity demand and renewable electricity generation on behalf of Germany's Transmission System Operators (TSOs) (IE, 2011; Prognos, 2011) were used. These projections expect gross electricity consumption to decrease over the coming years while renewable electricity generation is expected to continue to grow significantly. In 2013, the additional electricity generation from renewable sources, compared to the pre phase-out situation in 2010, is projected to be higher than the loss of nuclear electricity from the six (previously operational) NPPs. For simplicity, we assume here a balance in electricity imports and exports for Germany in 2012 and $2013^{7}$ (whereas Germany actually realised net exports of 17.7 TWh in 2010 6.0 TWh in 2011 and 7.8 TWh in the first half of $2012^{8}$ ).

\subsection{Outlook until 2025}

Compensating for the closure of eight NPPs is only the first step of the nuclear phase-out in Germany. Current law states that by the end of 2022 the remaining nine NPPs have to be shut down. In the following section we evaluate whether all NPPs ${ }^{9}$, which in 2010 generated roughly $140 \mathrm{TWh}$, can eventually be compensated for by additional domestic renewable power generation.

The following table compares annual renewable electricity generation projections of two recent scenario studies commissioned by the federal ministries of environment (BMU) and economy (BMWi) with the mid-term projections (which end in 2016) for the electricity system operators (TSOs). Also shown are the official expectations at federal level - as described in Germany's National Renewable Energy Action Plan submitted to the European Commission in 2010 - and the expected combined effects of the political targets set individually by the German federal states ('Länder').

\footnotetext{
${ }^{6}$ According to preliminary statistical data, renewable energy sources reached a share of $24 \%$ in German gross electricity generation in the first half of 2012 (BDEW 2012c). This compares with 20\% in 2010, 7\% in 2000 and 4\% in 1990 (AG Energiebilanzen 2012).

7 This may go along with an increasing volume of exports and imports due to the need for Germany and its neighbours to balance increasing amounts of fluctuating renewable electricity generation.

${ }^{8}$ Due to its location in the centre of Europe, Germany has always imported and exported significant amounts of electricity. At about 40 to $60 \mathrm{TWh} / \mathrm{a}$ both imports and exports have, in recent years, been in the range of $10 \%$ of annual domestic electricity generation. The main reasons for this significant exchange of electricity are the short and long-term balancing of power supply, as well as the transit of electricity through the German grid. For example, electricity generated in France and used in Italy is partly delivered via the German and Swiss grids.

${ }^{9}$ Of the 17 NPPs only 15 were in operation in 2010 , see above.
} 
Table: Gross electricity generation (in TWh) from domestic renewable energy sources; comparison of scenarios and political ambitions (2010 to 2025)

\begin{tabular}{|c|c|c|c|c|c|c|c|}
\hline & & 2010 & 2011 & 2015 & 2020 & 2025 & $\begin{array}{c}2025 \mathrm{vs} . \\
2010\end{array}$ \\
\hline Actual & $\mathrm{a}$ & 103 & 122 & - & - & - & - \\
\hline \multirow{3}{*}{$\begin{array}{l}\text { Scenarios/ } \\
\text { projections }\end{array}$} & TSOs b & - & 122 & 174 & - & - & - \\
\hline & $\mathrm{BMU}$ c & 103 & 116 & 166 & 234 & 283 & +180 \\
\hline & BMWi d & - & - & 161 & 199 & 231 & +128 \\
\hline \multirow{2}{*}{$\begin{array}{l}\text { Political } \\
\text { targets/ } \\
\text { expecta- } \\
\text { tions }\end{array}$} & NREAP e & 105 & 116 & 168 & 217 & - & - \\
\hline & Länder ${ }^{f}$ & - & - & - & 315 & - & - \\
\hline
\end{tabular}

The table shows that the two scenario studies (BMU, 2012; BMWi, 2011) provide a range of expectations regarding electricity generation from renewables, mainly for 2020 and 2025. The scenario for the ministry of environment (BMU, 2012) expects renewable electricity generation to reach 283 TWh/a by 2025 while the scenario for the ministry of economy (BMWi, 2011; Fürsch et al. 2012) foresees 231 TWh/a (or 18\% less) by the same year. The recent projections for the TSOs indicate that until 2015 growth in renewable electricity generation might actually exceed the expectations in both scenarios, mainly due to the current fast expansion of solar PV. For 2020 the German government's expectations (as expressed in its National Renewable Energy Action Plan) are in between the figures found in the two scenarios from both ministries. The current political targets of the Länder - which have been influenced to some extent by Fukushima - are as a sum significantly more ambitious than both the scenarios and also the federal government's expectations.

For 2020 different expectations about the growth in onshore wind capacity are mainly responsible for the differences between the scenarios and the political targets of the Länder. As onshore wind is a technology that is already relatively close to being competitive even without support measures, its deployment depends to a significant extent on the states and the municipalities, who are together responsible for planning the sites of wind power plants. In 2025 the main difference between the two scenarios lies in offshore wind capacity, but differences in solar PV deployment also play an important role (see Table S2 in the supplementary material).

This overview makes it clear that current deployment trends, as well as current political targets, indicate continued strong growth in renewable electricity generation over the coming years. Therefore, it seems likely that in comparison to 2010, by 2025 renewables will additionally supply at least the same amount of electricity as was produced by all of Germany's NPPs before the 2011 phase-out decision (about 140 TWh/a). This outcome does, of course, presuppose that the challenges of such rapid change in the method of generating electricity will be met successfully. In particular, the timely adaptation and expansion of the electricity grids, i.e. of high voltage as well as medium and low-voltage transmission and distribution lines, are critical factors in ensuring a positive outcome. 


\section{Effects on $\mathrm{CO}_{2}$ emissions of fossil power generation}

Electricity sector $\mathrm{CO}_{2}$ emissions in 2011 were only slightly higher $(+0.7 \%)$ than in 2010 (UBA, 2012) as the reduction in electricity supply from nuclear energy ${ }^{10}$ was almost entirely compensated by the combined effects of more renewables, lower net electricity exports and slightly lower domestic electricity demand. Fossil fuel use and related emissions, however, would ceteris paribus have been lower in 2011 than in 2010 if the eight NPPs (six of which were actually in operation in 2010) had not been shut down, as the additional carbon-free electricity would have replaced electricity generation in conventional fossil fuel power plants. Both electricity generation from fossil fuels and electricity sector $\mathrm{CO}_{2}$ emissions would have likely been 5 to 6\% lower in 2011 compared to 2010 if it had not been for the shutdown of the 8 NPPs. ${ }^{11}$

Nevertheless, to understand the bigger picture it has to be taken into account that Germany's fossil fuel power plants operate within the European Union's Emissions Trading System (ETS). Overall, $\mathrm{CO}_{2}$ emissions within the EU are expected to be unaffected by the phase-out decision as there is a firm cap on total emissions within the EU ETS and this cap has already been fixed for the forthcoming years. This means that additional emissions - or slower reductions - from the German electricity sector would 'only' lead to higher prices for $\mathrm{CO}_{2}$ emission allowances in the ETS in comparison to a nuclear prolongation path.

Furthermore - in the medium to long term - a (faster) nuclear phase-out does not necessarily imply higher $\mathrm{CO}_{2}$ emissions from the German electricity sector itself. For example, as the German Advisory Council on the Environment has pointed out (SRU, 2010), lifetime extensions for nuclear power plants would have imposed a significant barrier to the further growth of renewable energy technologies, to the increased use of combined heat and power plants and to the successful reduction in electricity demand. The incompatibility between nuclear power and high shares of renewable energy is mainly due to the inability of the former (technically as well as economically) to provide the operational flexibility that the integration of high levels of fluctuating renewable energy sources requires. The limited mitigation potential of nuclear power plants in an electricity system dominated by variable renewable generation, such as wind and solar, are demonstrated in modelling studies by Denholm/Hand (2011) and Hart/Jacobson (2012).12

While current regulation in Germany ${ }^{13}$ makes the expansion of renewable energy plants economically attractive independent of the role of nuclear power, it is likely that these

\footnotetext{
${ }^{10} \mathrm{As}$ is the case with most renewable energy plants, NPPs do not emit any $\mathrm{CO}_{2}$ during electricity generation itself, though there are some life-cycle $\mathrm{CO}_{2}$ emissions (Weisser, 2007).

11 These figures were calculated based on the assumptions that without the shutdown the German NPPs would have generated the same amount of electricity in 2011 as they did in 2010 (140.5 TWh), that electricity generation from renewables in 2011 would have been unaffected (122 TWh) due to a stable support scheme and priority grid access for renewables and that net exports would not have decreased from 17.7 TWh in 2010 to 6 TWh in 2011 but would have remained unchanged at the 2010 level.

12 See also Verbruggen (2008) for a discussion about the difficulties of combining renewable energy sources and nuclear power in a long-term mitigation strategy.

${ }^{13}$ As in many other European countries, feed-in tariffs are used in Germany to support electricity generation from renewables (Mitchell et al., 2006; Huenteler et al. 2012). The German feed-in-law (Renewable Energy Sources Act, EEG) stipulates fixed technology-specific tariffs to be paid (in most cases for a time span of 20 years) to the operators of renewable energy plants for each kWh they feed into the grid. The additional costs of renewables are shared among electricity consumers, though some consumers are exempted from having to pay the (full) share. The EEG also grants electricity generated from renewable sources priority access to the electricity grid. The combination of fixed feed-in tariffs and
} 
favourable political conditions for renewables would have come under much greater pressure from the politically influential energy companies that own the nuclear power plants if it had not been for the phase-out decision. It is, therefore, plausible to assume that in the medium to long-term renewable energy sources will be used to a greater extent in Germany's power sector compared to the hypothetical situation of a much slower nuclear phase-out. Consequently, energy generated from renewable sources (as opposed to fossil fuels) will eventually compensate at least partially for the electricity no longer generated in nuclear power plants.

To assess the potential development of $\mathrm{CO}_{2}$ emissions from power generation in Germany we sketch two different scenarios. Both assume the current phase-out plan as a given. The optimistic scenario combines a successful policy to reduce electricity demand with a switch within fossil generation from coal and lignite towards natural gas and the increased use of combined heat and power ${ }^{14}$ and especially of renewables as described in the scenario study for the Ministry of Environment (BMU, 2012). In such an optimistic scenario, $\mathrm{CO}_{2}$ emissions produced from German power generation would be around 50\% lower in 2020 than in 1990 (see Tables S2 and S3 in the supplementary material). Despite the nuclear phase-out, the electricity sector would contribute disproportionately to the German government's greenhouse gas reduction target of minus $40 \%$ by 2020 (vs. 1990).

However, in a more pessimistic scenario in which electricity consumption remains stable and renewable electricity generation increases only as assumed in the most recent scenario for the ministry of economy (BMWi 2011; Fürsch et al. 2012), the use of coal and lignite are reduced only slowly. The $\mathrm{CO}_{2}$ reduction from Germany's electricity production would only decrease by around $20 \%$ to $25 \%$ by 2020 (see also Tables S3 and S4).

This makes it clear that the relationship between nuclear electricity generation and $\mathrm{CO}_{2}$ emissions in the short-term is not a straightforward one. As a long-term perspective, the scenarios show that the electricity sector may significantly contribute to GHG reductions despite the nuclear phase-out. But this would need strong policy to promote in particular electricity savings, renewable generation and combined heat and power generation and a strengthening of the emission trading system in order to increase $\mathrm{CO}_{2}$-prices.

\section{Electricity price effects of a complete nuclear phase-out}

Increases in electricity prices and the subsequent problems for electricity intensive industries and low-income households were a major concern during the phase-out discussions in the spring and early summer of 2011. However, one year after the shutdown of around $40 \%$ of Germany's nuclear capacity, electricity prices on the wholesale market were actually lower than before the plants were closed ${ }^{15}$. The reason for this surprising

\footnotetext{
priority access leads to high security for renewable energy investors, independent of short-term changes in the electricity market.

14 Combined heat and power plants make use of the waste heat that occurs when electricity is generated using fossil fuels and biomass. Supplying this heat to consumers avoids the need for these consumers to generate heat themselves and, therefore, saves (fossil) energy.

${ }^{15}$ For example the price on the German wholesale market (see EEX 2012) for one MWh of electricity to be generated and delivered in 2013 was on average 1\% higher in February 2012 than it was in February 2011, before the eight NPPs were shut down. In May 2012 the average price was actually $8 \%$ lower than in February 2011. There was, however, a brief period of about three months immediately following the decision to shut down the eight NPPs when electricity prices were higher. Prices started to fall again in June 2011.
} 
effect is probably that trends other than nuclear capacity exert greater influence on short-term electricity prices (see Nestle 2012, 155 ff). Future electricity demand forecasts may have decreased between early 2011 and early 2012 as all the main economic forecasts were lowered during that period. It is likely that this change, combined with falling $\mathrm{CO}_{2}$ emission prices, had a dampening effect on electricity prices.

This does mean that without the shutdown and the phase-out decision, electricity prices might have been even lower than they are currently. Such an effect can only be estimated with electricity market models as has been done in a number of recent studies. Some of these studies were conducted before the 2010 decision to prolong nuclear lifetimes; consequently they estimate price reductions that may have been caused by a prolongation of nuclear lifetimes. Other studies were conducted in the spring of 2011 when the prolongation had been enacted and its reversal was being discussed in the aftermath of Fukushima. These studies analysed the effects of a faster phase-out as compared to the prolonged lifetimes decided on in 2010.

To support the political decision of a lifetime expansion, in the autumn of 2010 the government contracted a scenario study (BMWi 2010; Nagl et al. 2011). By using an electricity market model the study predicted lower electricity prices for scenarios with longer lifetime extensions until 2030. In a second set of scenarios that assumed higher retrofit investment levels for the existing NPPs they showed, however, the opposite result $(\mathrm{Nagl}$ et al. 2011, 191). Nestle $(2012,153)$ reports a couple of older studies with similar methodology and partly by the same authors that predicted electricity price reductions of 1 to 2 Euro-cent/kWh as a result of nuclear lifetime extensions.

During the spring and summer of 2011 further modelling studies were prepared (r2b, 2011, enervis, 2011; Kemfert/Traber, 2011; Knopf et al., 2011, BMWI 2011) that attempted to calculate the effects on electricity prices of a faster nuclear power phase-out. According to these studies the electricity price for end users in a fast phase-out scenario can be expected to be (temporarily) 0.5 to 1.3 Euro-cent/kWh above the price level of a scenario with a nuclear phase-out well after the year 203016. In a meta-analysis Samadi et al. (2011) showed that this could be an overestimation due to two main reasons. Firstly, the studies assumed that the phase-out would happen three to five years earlier than is planned. Secondly, the studies assumed constant electricity demand despite increasing prices and a government target to reduce demand - but both these factors would work against an increase in prices resulting from a faster phase-out (Knopf et al. 2011).

Based on this discussion Samadi et al. (2011) conclude that it is likely that electricity prices for end users would rise by no more than 0.7 Euro-cent/kWh as a consequence of a faster nuclear phase-out and that any such increase would be temporary. It is, however, debatable whether this relatively moderate price increase would actually occur. Nestle $(2012,153 \mathrm{ff})$ presents a number of arguments supporting the idea that the studies' results could still be exaggerating the de facto effects of longer nuclear lifetimes. He argues that all studies use market models that assume a perfect market, which definitely does not exist in Germany. Instead, in real life longer nuclear lifetimes would strengthen ex-

\footnotetext{
16 Those studies that take a longer-term view (especially enervis, 2011) indicate that only a few years after completion of an early phase-out the price difference between such a scenario and a late phase-out scenario can be expected to be mostly or entirely gone. Another study by Kunz et al. (2011) simulates a typical November day for the entire European electricity system. They find that the price effects of the phase-out of the seven oldest NPPs would occur mainly during evening peaks and would be on average only 'a few Euros per MWh' (Kunz et al. 2011, 7).
} 
isting oligopolistic structures ${ }^{17}$ and, therefore, might lead to increased prices instead of decreased prices, Nestle argues. He further presents several empirical findings from Germany and Europe that do not show any indication that high nuclear shares mean lower electricity prices. Finally, Nestle makes the point that in the long term, security of investment is decisive in providing low electricity prices. Following the (now reversed) decision to prolong the lifetimes of nuclear power plants, however, security of investment was significantly reduced in Germany due to several lawsuits contesting the political decision and the announcement by the political opposition to revoke the lifetime extensions as soon as they were back in power (Nestle 2012,157). The phase-out that has now been decided upon is the result of a political consensus between all major parties in Germany and this has, therefore, provided greater certainty for investors ${ }^{18}$.

\section{Conclusion}

Despite initial concerns about Germany's decision to phase out nuclear power by 2022, recent statistics as well as scenarios and political targets show that Germany has a realistic chance of fully replacing nuclear power with renewable electricity generation on an annual basis, provided that several related challenges, e.g. the expansion of the grids and provision of balancing power, can be solved successfully. By as early as 2011, the share of renewable energy sources in gross electricity generation was at $20 \%$, which for the first time since the early years of nuclear power in Germany in the mid 1970s was higher than the respective share of nuclear power (about 18\% in 2011). Despite phasing out nuclear power, Germany does not have to become a net electricity importer, nor will Germany be unable to gradually reduce fossil fuel generated electricity. Whether this will be sufficient to adequately contribute to national greenhouse gas mitigation targets significantly depends on an active policy to promote electricity savings, as well as the further expansion of renewables and combined heat and power generation.

The fact that Germany was able to achieve its nuclear policy turnaround so smoothly in 2011 by (already in the first year) replacing as much as $60 \%$ of the reduced nuclear power generation with additional renewable electricity is not surprising. An important reason is that the phase-out decision made in 2011 is technically very similar to the initial German phase-out plans that were already in place between 2002 and the autumn of 2010. This meant that the German energy industry was prepared and the feed-in-tariff system ratified in the year 2000 through the Renewable Energy Sources Act was particularly effective in significantly increasing electricity supply from renewable sources. Germany's 'trust in renewable energy innovation', as Wittneben (2011) put it, appears to be justified. The successful expansion of renewable energy use in the electricity sector in Germany in recent years was also pinpointed as the main reason that the Ethics Commission for a Safe Energy Supply, as established by Chancellor Merkel in March 2011, supported a quick nuclear phase-out. This commission concluded that Germany does, in fact, have 'less risky alternatives' than nuclear and should, therefore, use these alternatives (Ethics Commission for a Safe Energy Supply, 2011).

\footnotetext{
17 The assumption of oligopolistic or even duopolistic structures in the German electricity market is shared by several other authors, e.g. Liebau/Ströbele $(2011,23)$, Bohne $(2011,260)$ and Langniß et al. $(2009,1291)$.

18 The current phase-out (compared to the situation before 2010 when the old phase-out decision was in place) has an even broader societal consensus behind it. This of course increases the opportunities for stable and clear investment frameworks in years to come. However, switching to renewable electricity imposes new challenges and also uncertainties, which will also have to be dealt with in order to deliver a stable framework.
} 


\section{Acknowledgements}

The authors would like to thank two anonymous reviewers and especially associate editor Raul Lejano for their valuable comments and suggestions to earlier versions of this paper. The development of this paper has benefited substantially from their comments and suggestions.

\section{References}

AG Energiebilanzen, 2012. Stromerzeugung nach Energieträgern von 1990 bis 2011 (in TWh) Deutschland insgesamt, available on http://www.agenergiebilanzen.de/viewpage.php?idpage=65, last accessed on 14 August 2012.

BDEW, 2011. Entwicklungen in der Stromwirtschaft 2011, Presentation by Michael Nickel during the meeting of the Arbeitsgemeinschaft Energiebilanzen on 16 December 2011, agenergiebilanzen.de/componenten/download.php?filedata=1324204440.pdf\&filename=2011_Strom.p df\&mimetype=application/pdf, last accessed on 21 August 2012.

BDEW, 2012a. Energieverbrauch in Deutschland, Daten für das 1.-4. Quartal 2011, agenergiebilanzen.de/componenten/download.php?filedata=1327316404.pdf\&filename=Quartalsberic ht_Q4_2011_23.1.2012.pdf\&mimetype=application/pdf, last accessed on 21 August 2012.

BDEW, 2012b. Energieverbrauch in Deutschland, Daten für das 1. Quartal 2012, http://www.agenergiebilanzen.de?Q12012, last accessed on 21 August 2012.

BDEW, 2012c. Entwicklungen in der deutschen Stromwirtschaft im 1. Halbjahr 2012, Presentation by Michael Nickel during the meeting of the Arbeitsgemeinschaft Energiebilanzen on 26 and 27 July 2012, agenergiebilanzen.de/componenten/download.php?filedata=1343640979.pdf\&filename=Strom_HJ201 2.pdf\&mimetype=application/pdf, last accessed on 21 August 2012.

BMU, 2012. Langfristszenarien und Strategien für den Ausbau der erneuerbaren Energien in Deutschland bei Berücksichtigung der Entwicklung in Europa und global, http://erneuerbareenergien.de/files/pdfs/allgemein/application/pdf/leitstudie2011_bf.pdf, last accessed on 19 June 2012.

BMWi, 2010. Energieszenarien für ein Energiekonzept der Bundesregierung, http://www.bmwi.de/BMWi/Redaktion/PDF/Publikationen/Studien/studieenergieszenarien-fuer-einenergiekonzept,property=pdf,bereich=bmwi2012, sprache $=$ de,rwb=true.pdf, last accessed on 21 August 2012.

BMWi, 2011. Energieszenarien 2011, http://www.prognos.com/fileadmin/pdf/publikationsdatenbank/11_08_12_Energiesze narien_2011.pdf, last accessed on 2 January 2012.

Bohne, E., 2011. Conflicts between national regulatory cultures and EU energy regulations, Utilities Policy, Vol. 19, pp. 255-269.

Bosman, R., 2012. Germany's 'Energiewende', clingendael international energy programme briefing papers, http://www.clingendael.nl/publications/2012/20120215_ciep_briefingpaper_rbosman_ germany_energiewende.pdf, last accessed on 1 July 2012.

dena, 2011. Presentation by Stephan Kohler during a meeting of the Arbeitsgruppe Netzentwicklungsplan on 5 July 2011 in Berlin, http://www.dena.de/fileadmin/user_upload/Download/Dokumente/Projekte/ESD/110 705_AGNEP_dena_Bericht_PlattformNetze.pdf, last accessed on 2 January 2012. 
Denholm, P., Hand, M., 2011. Grid flexibility and storage required to achieve very high penetration of variable renewable electricity, Energy Policy, Vol. 39, pp. 1817-1830.

destatis, 2012. Elektrizitätserzeugung, Nettowärmeerzeugung, Brennstoffeinsatz: Deutschland, Monate, Energieträger, https://www-genesis.destatis.de/genesis/online, last accessed on 21 August 2012.

EEX, 2012. Market data - Phelix Futures, http://www.eex.com/en/Market\%20Data/Trading\%20Data/Power/Phelix\%20Futures \%20\%7C\%20Derivatives, last accessed on 19 June 2012.

enervis, 2011. Atomausstieg bis zum Jahr 2020: Auswirkungen auf Investitionen und Wettbewerb in der Stromerzeugung - Kurzstudie, http://www.enervis.de/images/stories/enervis/pdf/publikationen/gutachten/110509_ kurzgutachten_enervis_atomausstieg_2020.pdf, last accessed on 01 July 2012.

Ethics Commission for a Safe Energy Supply, 2011. Germany's energy transition - A collective project for the future, Berlin, 30th May 2011, http://www.bundesregierung.de/Content/DE/_Anlagen/2011/05/2011-05-30abschlussbericht-ethikkommission_en,property=publicationFile.pdf, last accessed on 2 January 2012.

Fürsch, M., Lindenberger, D., Malischek, R., Nagl, S., Panke, T., Trüby, J., 2012. German Nuclear Policy Reconsidered: Implications for the Electricity Market, Economics of Energy \& Environmental Policy Volume 1, Number 3, http://dx.doi.org/10.5547/2160-5890.1.3.4

German Government, 2010. National Renewable Energy Action Plan in accordance with Directive 2009/28/EC on the promotion of the use of energy from renewable sources, http://ec.europa.eu/energy/renewables/transparency_platform/doc/national_renewab le_energy_action_plan_germany_en.pdf, last accessed on 2 January 2012.

Hart, E.K., Jacobson, M.Z., 2012. The carbon abatement potential of high penetration intermittent renewables, Energy \& Environmental Science, Vol. 5, pp. 6592-6601.

Huenteler, J., Schmidt, T.S., Kanie, N., 2012. Japan's post-Fukushima challenge - imiplications from the German experience on renewable energy policy, Energy Policy, Vol. 45, pp. 6-11.

IAEA, 2012. Power Reactor Information System, available on http://www.iaea.org/programmes/a2/, last accessed on 2 January 2012.

IE, 2011. Mittelfristprognose zur deutschlandweiten Stromerzeugung aus regenerativen Kraftwerken bis 2016, http://www.eeg-kwk.net/de/file/111115_IE-Leipzig_EEGMittelfristprognose_bis_2016.pdf, last accessed on 2 January 2012.

Jahn, D., Korolczuk, S., 2012: German exceptionalism: the end of nuclear energy in Germany!, Environmental Politics, Vol. 21, pp. 159-164.

Kemfert, C., Traber, T., 2011. Atom-Moratorium: Keine Stromausfälle zu befürchten, http://www.diw.de/documents/publikationen/73/diw_01.c.372712.de/11-20-1.pdf, last accessed on 1 July 2012.

Knopf, B., Kondziella, H., Pahle, M., Götz, M., Bruckner, T., Edenhofer, O., 2011. Der Einstieg in den Ausstieg - Energiepolitische Szenarien für einen Atomausstieg in Deutschland, http://library.fes.de/pdf-files/wiso/08340.pdf, last accessed on 1 July 2012.

Kunz, F., von Hirschhausen, C., Möst, D., Weigt, H., 2011. Security of supply and electricity network flows after a phase-out of Germany's nuclear plants: Any trouble ahead?, EUI Working Papers, RSCAS 2011/32, ISSN 1028-3625.

Langniß, O., Dieckmann, J., Lehr, U., 2009. Advanced mechanisms for the promotion of renewable energy - Models for the future evolution of the German Renewable Energy Act, Energy Policy, Vol. 37, pp. 1289-1297.

Liebau, B., Ströbele, W.J., 2011. The Shortcomings of the Architecture of the German Electricity Market, The Electricity Journal, Vol. 25, pp. 21-28. 
Mitchell, C., Bauknecht, D., Connor, P.M., 2006. Effectiveness through risk reduction: a comparison of the renewable obligation in England and Wales and the feed-in system in Germany, Energy Policy, Vol. 34, pp. 297-305.

Nagl, S., Fürsch, M., Paulus, M, Richter, J., Trüby, J., Lindenberger, D., 2011. Energy policy scenarios to reach challenging climate protection targets in the German electricity sector until 2050, Utilities Policy, Vol. 19, pp. 185-192.

Nestle, U., 2012. Does the use of nuclear power lead to lower electricity prices? An analysis of the debate in Germany with an international perspective; Energy Policy, Vol. 41, pp. 152-160.

Prognos, 2011. Letztverbrauch bis 2016 - Planungsprämissen für die Berechnung der EEGUmlage, http://www.eeg-

kwk.net/de/file/111115_Prognos_Letztverbrauch_bis_2016.pdf, last accessed on 2 January 2012.

r2b, 2011. Energieökonomische Analyse eines Ausstiegs aus der Kernenergie in Deutschland bis zum Jahr 2017, http://www.r2b-energy.com/pdf/Kurzfassung_Ausstieg2017.pdf, last accessed on 1 July 2012.

Samadi, S. Fischedick, M., Lechtenböhmer, S., Thomas, S., 2011. Kurzstudie zu Strompreiseffekten eines beschleunigten Ausstiegs aus der Nutzung der Kernenergie, Studie im Auftrag des Ministeriums für Klimaschutz, Umwelt, Landwirtschaft, Naturund Verbraucherschutz des Landes NRW, Wuppertal-Institut, Wuppertal, 18. Mai 2011, http://www.wupperinst.org/uploads/tx_wiprojekt/Strompreiseffekte_Endbericht.pdf, last accessed on 1 July 2012.

SRU, 2010. Climate-friendly, reliable, affordable: $100 \%$ renewable electricity supply by 2050 , http://www.umweltrat.de/SharedDocs/Downloads/EN/04_Statements/2010_05_State ment15_Renewablesby2050.pdf?_blob=publicationFile, last accessed on 2 January 2012.

UBA, 2012. Entwicklung der spezifischen Kohlendioxid-Emissionen des deutschen Strommix 1990-2010 und erste Schätzungen 2011, http://www.umweltbundesamt.de/energie/archiv/co2-strommix.pdf, last accessed on 14 August 2012.

Verbruggen, A., 2008. Renewable and nuclear power: A common future?, Energy Policy, Vol. 36, pp. 4036-4047.

Weisser, D., 2007. A guide to life-cycle greenhouse gas (GHG) emissions from electric supply technologies, Energy, Vol. 32, pp. 1543-1559.

Wittneben, B.B.F., 2011. The impact of the Fukushima nuclear accident on European energy policy, Environmental Science \& Policy, Vol. 15, pp. 1-3. 


\section{Supplementary Material}

Table S1: Compensation of reduced nuclear electricity generation between 2011 and 2013, based on preliminary statistics and projections (in TWh)

Reduced nuclear electricity generation (vs. 2010)

2011 a

2 Compensation (vs. 2010) by

Additional renewable electricity generation

32.5

$2012^{b}$

$2013^{b}$

Reduced net exports

19.2

40.9

40.9

Reduced domestic electricity demand

11.7

31.9

43.0

1.9

17.7

17.7

hange in domestic fossil power generation vs. 2010 (equals 1-2)

$-0.3 \quad-17.4$ $-32.1$

a Preliminary Statistics: AG Energiebilanzen (2012); ${ }^{b}$ Based on projections for TSOs: IE (2011), Prognos (2011), on IAEA (2012) and on own assumptions.

Explanation of the data in Table S1:

- Data for 2010 and 2011 is according to AG Energiebilanzen (2012).

- Data for 2012 and 2013 is based on the following sources and assumptions:

- Nuclear electricity generation is based on the assumption that each remaining nuclear power plant will have the same capacity factor (on average about 91\%) as it had over the years 2001 to 2010 (IAEA 2012).

- Additional renewable electricity generation as well as the changes in domestic electricity demand are based on projections prepared for the German transmission system operators (IE 2011 and Prognos 2011).

- For net exports it is assumed that Germany will export the same amount of electricity as it will import (net exports or net imports $=0$ ). 
Table S2: Electricity generation from domestic renewable energy by source in 2010 and 2011 as well as in 2016, 2020 and 2025 according to different projections, scenarios and political targets/expectations

\begin{tabular}{|c|c|c|c|c|c|c|}
\hline & 2010 & 2011 & \multicolumn{4}{|c|}{2016} \\
\hline & Actual & Actual* & $\begin{array}{c}\text { Scenario } \\
\text { for Min- } \\
\text { istry of } \\
\text { Env. }\end{array}$ & $\begin{array}{l}\text { Scenario } \\
\text { for Min- } \\
\text { istry of } \\
\text { Econ. }\end{array}$ & NREAP & $\begin{array}{l}\text { Projec- } \\
\text { tions for } \\
\text { TSOs }\end{array}$ \\
\hline Hydro & 21 & 20 & 22 & 19 & 19 & 23 \\
\hline Wind onshore & 38 & 46 & 67 & 65 & 65 & 63 \\
\hline Wind offshore & 0 & 1 & 12 & 14 & 11 & 21 \\
\hline Biomass & 32 & 37 & 45 & 43 & 44 & 42 \\
\hline Solar PV & 12 & 19 & 33 & 28 & 29 & 39 \\
\hline Geothermal & 0 & 0 & 1 & 1 & 1 & 0 \\
\hline \multirow[t]{3}{*}{ TOTAL } & 103 & 122 & 176 & 168 & 168 & 189 \\
\hline & \multicolumn{4}{|c|}{2020} & \multicolumn{2}{|c|}{2025} \\
\hline & $\begin{array}{c}\text { Scenario } \\
\text { for Min- } \\
\text { istry of } \\
\text { Env. }\end{array}$ & $\begin{array}{c}\text { Scenario } \\
\text { for Min- } \\
\text { istry of } \\
\text { Econ. }\end{array}$ & NREAP & $\begin{array}{c}\text { Sum of } \\
\text { targets of } \\
\text { German } \\
\text { States }\end{array}$ & $\begin{array}{c}\text { Scenario } \\
\text { for Min- } \\
\text { istry of } \\
\text { Env. }\end{array}$ & $\begin{array}{c}\text { Scenario } \\
\text { for Min- } \\
\text { istry of } \\
\text { Econ. }\end{array}$ \\
\hline Hydro & 22 & 20 & 20 & 23 & 23 & 24 \\
\hline Wind onshore & 82 & 69 & 73 & 145 & 91 & 76 \\
\hline Wind offshore & 33 & 32 & 32 & 55 & 61 & 44 \\
\hline Biomass & 50 & 44 & 49 & 49 & 53 & 49 \\
\hline Solar PV & 45 & 32 & 41 & 40 & 50 & 36 \\
\hline Geothermal & 2 & 1 & 2 & 3 & 4 & 2 \\
\hline TOTAL & 234 & 199 & 217 & 315 & 283 & 231 \\
\hline
\end{tabular}

Sources: AG Energiebilanzen (2012), BMWi (2011), BMU (2012), IE (2011), German Government (2010a), dena (2011).

*Preliminary data

Table S3: Gross electricity consumption, gross electricity generation according to energy source and net imports (in TWh) in 2000 and 2010 as well as in 2020 and 2025 in two different scenarios

\begin{tabular}{|c|c|c|c|c|c|c|c|}
\hline & & \multicolumn{2}{|c|}{ Actual } & \multicolumn{2}{|c|}{$\begin{array}{c}\text { Low Fossil Sce- } \\
\text { nario }\end{array}$} & \multicolumn{2}{|c|}{$\begin{array}{l}\text { High Fossil Sce- } \\
\text { nario }\end{array}$} \\
\hline & & 2000 & 2010 & 2020 & 2025 & 2020 & 2025 \\
\hline 1 & Gross electricity consumption & 580 & 610 & 553 & 538 & 609 & 609 \\
\hline 2 & Gross electricity generation & & & & & & \\
\hline $2 \mathrm{a}$ & Nuclear & 148 & 141 & 67 & 0 & 67 & 0 \\
\hline $2 b$ & Renewable & 38 & 103 & 234 & 283 & 199 & 231 \\
\hline $2 c$ & Fossil (equals 1-2a-2b-3) & 391 & 384 & 252 & 255 & 343 & 378 \\
\hline 3 & Net imports & 3 & -18 & 0 & 0 & 0 & 0 \\
\hline
\end{tabular}


Explanation of the data in Table S3:

Data for 2000 and 2010 is based on AG Energiebilanzen (2012).

Data for 2020 and 2025 for the two scenarios is based on the following sources and assumptions:

- Gross electricity consumption in the 'Low Fossil' scenario is based on the assumption that the German government's target of reducing electricity demand by $10 \%$ by 2020 and of $25 \%$ by 2050 (vs. 2008, see German Government 2010b) will be met. For the 'High Fossil' scenario it is assumed that electricity demand will remain stable at the 2011 level (2011 electricity demand is from AG Energiebilanzen 2012).

- Nuclear electricity generation is based on the assumption that each remaining nuclear power plant will remain in operation until the final day permitted under the current nuclear phase-out law. During this time each nuclear power plant will have the same capacity factor (on average about 91\%) as it had over the past ten years (IAEA 2012).

- Renewable electricity generation in the 'Low Fossil' scenario is taken from the scenario prepared for the German Ministry of the Environment (BMU 2012), while in the 'High Fossil' scenario it is taken from the scenario prepared for the German Ministry of the Economy (BMWi 2011). See also the figures for renewable electricity generation in Table S2.

- For net exports it is assumed that Germany will export the same amount of electricity as it will import (net imports $=0$ ).

Table S4: Fossil electricity generation, specific fossil $\mathrm{CO}_{2}$ emissions and electricity sector $\mathrm{CO}_{2}$ emissions in 1990 and 2010 as well as in 2020 and 2025 in two different scenarios

\begin{tabular}{|c|c|c|c|c|c|c|}
\hline & \multirow[b]{2}{*}{1990} & \multirow[b]{2}{*}{2010} & \multicolumn{2}{|c|}{$\begin{array}{l}\text { Low Fossil } \\
\text { Scenario }\end{array}$} & \multicolumn{2}{|c|}{$\begin{array}{c}\text { High Fossil } \\
\text { Scenario }\end{array}$} \\
\hline & & & 2020 & 2025 & 2020 & 2025 \\
\hline Fossil electricity generation (in TWh) & 378 & 385 & 252 & 255 & 341 & 376 \\
\hline Specific $\mathrm{CO}_{2}$ emissions (in $\mathrm{g} / \mathrm{kWh}_{\text {fossil }}$ ) & 945 & 785 & 709 & 657 & 816 & 717 \\
\hline Electricity sector $\mathrm{CO}_{2}$ emissions (in Mt) & 357 & 302 & 179 & 168 & 278 & 269 \\
\hline Change vs. 1990 & - & $-15 \%$ & $-50 \%$ & $-53 \%$ & $-22 \%$ & $-25 \%$ \\
\hline
\end{tabular}

Sources: Lechtenböhmer/Samadi (2012), UBA (2012), AG Energiebilanzen (2012), BMU (2012), $B M W i$ (2011). See Table S3 for additional sources used to derive fossil electricity generation for the two scenarios.

Explanation of the data in table S4:

Data for 1990 and 2010 is based on the following sources:

- UBA (2012) provides data for $\mathrm{CO}_{2}$ emissions from the electricity sector.

- AG Energiebilanzen (2012) provides data for fossil electricity generation.

The two scenarios have been further described in Lechtenböhmer/Samadi (2012): Data for 2025 for the two scenarios is based on the following sources and assumptions:

- Fossil electricity generation is derived as explained by Table S3.

- Specific $\mathrm{CO}_{2}$ emissions from fossil electricity generation are based on the rate of change shown in the scenario study for the German Ministry of the Environment (BMU, 2012, for the Low Fossil scenario) and on the rate of change shown in the scenario study for 
the German Ministry of the Economy (BMWi, 2011, for the High Fossil scenario). In the scenario of BMU (2012) electricity generation from natural gas power plants gains in relevance relative to electricity generation from coal and lignite, while this is not immediately the case in the BMWi (2011) scenario. This is the main reason for the differences in the specific $\mathrm{CO}_{2}$ emissions of fossil electricity generation. Another factor that can play a role is the rate at which the efficiency of fossil power plants improves. Furthermore, the use of Carbon Capture and Storage (CCS) technology can reduce specific $\mathrm{CO}_{2}$ emissions. CCS technology is used in the BMWi (2011) scenario, but only to a small extent by 2025. CCS technology is not used in the BMU (2012) scenario.

\section{References}

German Government, 2010a. National Renewable Energy Action Plan in accordance with Directive 2009/28/EC on the promotion of the use of energy from renewable sources, http://ec.europa.eu/energy/renewables/transparency_platform/doc/national_renewab le_energy_action_plan_germany_en.pdf, last accessed on 2 January 2012.

German Government, 2010b. Energy Concept for an Environmentally Sound, Reliable and Affordable Energy Supply,

http://www.bmu.de/files/english/pdf/application/pdf/energiekonzept_bundesregierun g_en.pdf, last accessed on 2 January 2012.

Lechtenböhmer, S., Samadi, S., 2012. Auswirkungen des Atomausstiegs auf die deutsche Stromerzeugung, Energiewirtschaftliche Tagesfragen, Vol. 62, pp. 34-38.

[All other references are listed in the main article.] 